\title{
Submental Anatomical Variations: The Uniqueness of a Common Variation
}

\author{
Laísa Caldas Fernandes,' Patricia Shirley de Almeida Prado ${ }^{2,3}$ \\ ${ }^{1}$ Hospital Santo Antonio, Salvador, BA, Brazil. \\ ${ }^{2}$ Department of Bio-morphology, Federal University of Bahia, Salvador, BA, Brazil. \\ 3Université Polytechnique Hauts-de-France \& INSA Hauts-de-France. LAMIH - UMR CNRS 8201, Département "Sciences de l'Homme et du \\ Vivant" (SHV). Campus Mont Houy, Valenciennes, France
}

Disclose and conflicts of interest: none to be declared by all authors

\begin{abstract}
Introduction: submental region is subject to many variations, predominantly affecting the anterior belly of the digastric muscle. The medical importance of this area led us to compile a database with the reported cases of the anomalous belly of the anterior belly of the digastric muscle as well as report one case.

During a dissection for didactic purposes of the submental region of an adult female formalin-fixed cadaver, a supernumerary belly in the digastric muscle and an abnormal muscle fibres arrangement were observed. No variation was detected in the posterior belly of the digastric muscle or in the intermediate tendon. To gather a database academic search tools such as Pubmed, Web of Science, Scopus and Google scholar using the keywords, accessory belly and abnormalities of digastric muscle, variations in the digastric muscle, variations in the submental region, agenesis and atrophy of digastric muscle.

A total of 114 cases were identified in the literature, 62 bilateral and 39 unilateral anomalies and 13 unknown data. From the 62 reported bilateral cases the symmetry was registered in 52 cases, 24 cases showed a symmetric pattern while 28 were asymmetric. The digastric muscle anterior belly variation is relatively frequent, however, its presentation and number are variable and in general unique. Moreover, this variation can easily be confused with pathological conditions. This article highlights the importance of reporting submental anatomical variations to strengthen epidemiological data so as to avoid misdiagnosis and point out the use of these structures as references for surgical procedures and imaging methods.

Keywords: Digastric muscle; Anatomical variation; Database; Misdiagnosis; Accessory belly.
\end{abstract}

\section{Introduction}

The structures of the submental region are key landmarks for several head and neck procedures, thus a knowledge of normal and variant anatomical aspects of this area is crucial. Due to its location, the digastric muscle is considered part of a set of suprahyoid muscles. Alongside the mylohyoid, the digastric muscle plays an important role as the floor of the oral cavity. It is responsible for the elevation of the hyoid bone and for the depressing of the mandible, enabling the opening of the mouth. ${ }^{1}$

With a particular embryological origin, the anterior and posterior bellies of the digastric muscle originate from the first and second pharyngeal arch respectively. Due to its diverse mesenchymal origin, the digastric muscle innervation is shared by both the facial and mylohyoid nerves (branch of the mandibular nerve) for the posterior and anterior bellies correspondingly. ${ }^{2}$

Anatomically, this muscle is divided into two parts, the anterior and posterior bellies on each side, and these are linked through the intermediate tendon. The anterior belly of digastric muscle is attached to the digastric fossa of themandible and then inclines downwards and backwards superficially to the mylohyoid muscle, while the posterior belly runs upwards and backwards to its attachment on the mastoid notch of the temporal bone. The intermediate tendon is inserted in the hyoid bone through a fibrous sling. ${ }^{1}$

The mylohyoid and the digastric muscle are intimately related. ${ }^{3}$ The anterior belly of the digastric muscle and the mylohyoid muscle partially share the innervation (mylohyoid branch of inferior alveolar nerve) and blood supply (submental branches of facial artery) and have similar actions on the hyoid bone and mandible. Moreover, cases of the anterior belly of the digastric muscle fibres merging with mylohyoid fibres are well documented in the literature. ${ }^{4,1}$

Anatomical variations in the submandibular region are frequent andauthors have been studying the submental region for a long time in an attempt to describe5, classify and nominate the variations e.g. $\mathrm{m}$. Mento-hyoid (Macalister) ${ }^{4}$ and $\mathrm{m}$. Interdigastricus. ${ }^{6}$ The literature presents records of the variations in the digastric muscle dating from 17377 and since then several authors have published anatomical studies 
in the submental and submandibular anatomical regions $^{8,9,10,11,12,13,14,15,16,17,18,19}$ as well as many others who have been publishing their findings as case reports (see the list of authors in Table 1).

The digastric accessory anterior belly (ABDM) is the most common variation in this region and the accessory belly can be divided and/or inserted into different locations of the mandible and hyoid bone 14,20. The agenesis and/or atrophy of the anterior belly of the digastric muscle can reach up to $40 \%$ in some pathological conditions such as hemifacial microssomia. On the other hand, in a non-syndromic population the agenesis of the ABDM is considered a rare phenomenon. ${ }^{21}$

Anatomical variations in the submental region may be misinterpreted as pathological conditions. Therefore a solid understanding of the anatomy and recognition of these variations in the analysis of imaging exams such as Computed tomography (CT) and Magnetic resonance imaging (MRI) and in surgical procedures is required to avoid misdiagnosis, imprecision in surgical procedures as well as in emergency interventions. ${ }^{10,18,22,23,24}$

\section{Case Report}

During a routine anatomical dissection of the suprahyoid region of a 42 year-old female formalinfixed cadaver in the Anatomy Laboratory at Federal University of Bahia, we discovered an accessory belly of the anterior portion of the digastric muscle.

The mandibular insertion of accessory belly was positioned medially to the anterior belly of the right digastric muscle in the right digastric fossa of mandible with an oblique trajectory to the left side, attachedinto the hyoid bone close to the medial border of the ABDM on the left side (see Fig 1).

Figure 1 - In a closer investigation, we noticed irregular muscle fibres from the hyoid end of right ABDM and the accessory belly merging with the fibres of the mylohyoid muscle at the topography of its median raphe (Fig 2).



Figure 1. Inferior view of right and left submandibular areas showing the accessory belly (1) of the digastric muscle anterior belly, note the origin of the variation close to the right anterior digastric belly (3) heading to the left anterior digastric belly (3'). (+): Hyoid bone; (2): Right mylohyoid muscle; (2'): Left mylohyoid muscle; (*): Mandible. 
Figure 2 - Despite these abnormal merging fibres, the anterior and posterior bellies showed a normal insertion and trajectory on both sides of the neck. The length (lateral and medial margins) and width of the anterior bellies were measured with a manual calliper. The measurements obtained were approximately as follows: right belly $26 \mathrm{~mm}, 35 \mathrm{~mm}$ and $15 \mathrm{~mm}$; left belly $28 \mathrm{~mm}, 38 \mathrm{~mm}$ and $14 \mathrm{~mm}$, respectively; and accessory belly right border $30 \mathrm{~mm}$, left border $35 \mathrm{~mm}$ and $8 \mathrm{~mm}$ width. data. From the 62 reported bilateral cases the symmetry was registered in 52 cases, 24 cases showed a symmetric pattern while 28 were asymmetric.

From 39 reports of unilateral variation, 14 cases the extra belly was found on the right side, 10 on the left side and 7 located in the middle or crossing the midline. There were 8 cases without side information of unilateral variation (see table 01).

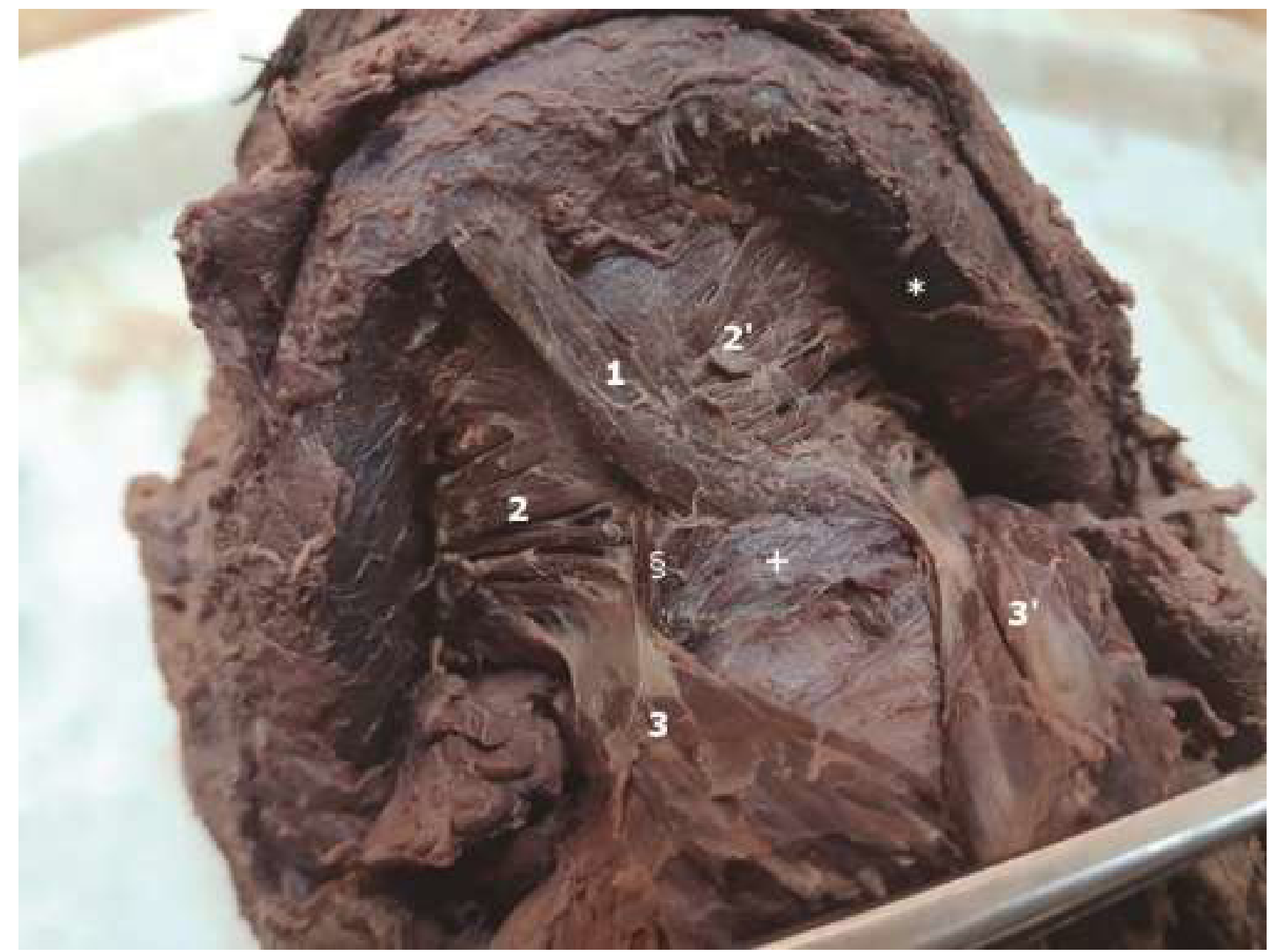

Figure 2. Inferior view of right and left submandibular areas. The anterior bellies of the digastric muscle are folded down ( 3 and $3^{\prime}$ ) to show the mylohyoid muscle ( 2 and $\left.2^{\prime}\right)$. Related to the Hyoid bone (+) the irregular muscle bundle (§) linked to the anterior belly of the right digastric muscle running in an oblique direction towards the mylohyoid muscle (2).

*: Mandible; 1: Digastric muscle variation.

We observed no other variation or pathological process on the suprahyoid or infrahyoid region of this individual.

The case study was performed according to the rules of the Brazilian Ethics Committee and the Ethical regulation for using cadavers for research purpose of the Federal University of Bahia.

\section{Results}

A total of 114 cases were identified in the literature, 62 bilateral and 39 unilateral anomalies and 13 unknown

\section{Discussion}

The accessory belly of ABDM is considered the most common variations of the submandibular region, the supernumerary muscle can be attached in different structures and muscle of the submental region, such as the digastric muscle, digastric intermediate tendon, hyoid bone, mandible, mylohyoid raphe or even the mylohyoid muscle. ${ }^{25,14,20,26,3}$ Likewise, the digastric muscle variations are more likely to occur in the submental triangle. ${ }^{23}$ 
Table 1. variation on the anterior belly of digastric muscle reported in the literature.

\begin{tabular}{|c|c|c|c|c|c|c|c|c|c|c|c|}
\hline \multicolumn{12}{|c|}{ Unilateral variation - Unique belly } \\
\hline $\begin{array}{c}\text { Case } \\
\mathbf{N}\end{array}$ & $\begin{array}{l}\text { Side and } \\
\text { symmetry }\end{array}$ & $\begin{array}{c}\text { Atypical } \\
\text { bellies }\end{array}$ & Study & Morphology & Reference & $\begin{array}{c}\text { Case } \\
\mathbf{N}\end{array}$ & $\begin{array}{l}\text { Side and } \\
\text { symmetry }\end{array}$ & $\begin{array}{c}\text { Atypical } \\
\text { bellies }\end{array}$ & Study & Morphology & Reference \\
\hline 1 & $\mathrm{U}(\mathrm{C})$ & 1 & AS & & $\begin{array}{l}\text { Larsson and } \\
\text { Lufkin }^{24}\end{array}$ & 2 & $U(R)$ & 1 & CR & & $\begin{array}{c}\text { Sargon } \\
\text { and } \\
\text { Çelik }^{44}\end{array}$ \\
\hline 3 & $U(M)$ & 1 & CR & & $\begin{array}{c}\text { Guelfgu at } \\
\text { et } a l^{14}\end{array}$ & 4 & $\mathrm{U}(\mathrm{C})$ & 1 & AS & & $\begin{array}{c}\text { Sakamoto } \\
\text { and } \\
\text { Akita }^{43}\end{array}$ \\
\hline 5 & $\mathrm{U}(\mathrm{C})$ & 1 & AS & & $\begin{array}{l}\text { Sakamot o } \\
\text { and Akita }{ }^{43}\end{array}$ & 6 & $U(R)$ & 1 & AS & & $\begin{array}{l}\text { Liquidato } \\
\text { et } a l^{26}\end{array}$ \\
\hline 7 & $U(R)$ & 1 & AS & & $\begin{array}{l}\text { Liquidat o } \\
\text { et } a^{26}\end{array}$ & 8 & $\mathrm{U}(\mathrm{L})$ & 1 & CR & & $\begin{array}{l}\text { Bakirci } \\
\text { et al }\end{array}$ \\
\hline 9 & $\mathrm{U}(\mathrm{R}$ to $\mathrm{L})$ & 1 & CR & & $\begin{array}{c}\text { Karunak } \\
\text { aran et al }{ }^{21}\end{array}$ & 10 & $\mathrm{U}(\mathrm{C})$ & 1 & CR & & $\begin{array}{c}\text { Bonala } \\
\text { et } a l^{7}\end{array}$ \\
\hline 11 & $U(R)$ & 1 & $\mathrm{CR}$ & & $\begin{array}{l}\text { Heyduk } \\
\text { et } a l^{18}\end{array}$ & 12 & $U(R)$ & 1 & CR & & $\begin{array}{l}\text { Heyduk } \\
\text { et } a^{18}\end{array}$ \\
\hline 13 & $U(R)$ & 1 & $\mathrm{CR}$ & & $\begin{array}{l}\text { Accioly Lins } \\
\text { et } a l^{1}\end{array}$ & 14 & $U(R)$ & 1 & CR & & $\begin{array}{c}\text { Fernandes } \\
\text { and } \\
\text { Almeida } \\
\text { Prado } \\
\text { (2019) }\end{array}$ \\
\hline
\end{tabular}

Unilateral variation - Multiple bellies

\begin{tabular}{|c|c|c|c|c|c|c|c|c|c|c|c|}
\hline $\begin{array}{c}\text { Case } \\
\mathbf{N}\end{array}$ & $\begin{array}{l}\text { Side and } \\
\text { symmetry }\end{array}$ & $\begin{array}{c}\text { Atypical } \\
\text { bellies }\end{array}$ & Study & Morphology & Reference & $\begin{array}{c}\text { Case } \\
\mathbf{N}\end{array}$ & $\begin{array}{l}\text { Side and } \\
\text { symmetry }\end{array}$ & $\begin{array}{l}\text { Atypical } \\
\text { bellies }\end{array}$ & Study & Morphology & Reference \\
\hline 15 & $U(R)$ & 3 & CR & & Çelik et al ${ }^{10}$ & 16 & U (L) & 4 & CR & & $\begin{array}{l}\text { Çelik } \\
\text { et } a l^{11}\end{array}$ \\
\hline 17 & $U(R)$ & 4 & AS & & $\begin{array}{l}\text { Sakamot o } \\
\text { and Akita }{ }^{43}\end{array}$ & 18 & $\mathrm{U}(\mathrm{L})$ & 2 & AS & & $\begin{array}{l}\text { Ozgur } \\
\text { et } a l^{37}\end{array}$ \\
\hline 19 & $\begin{array}{l}\mathrm{U}(\mathrm{M} \text { and } \\
\mathrm{L})^{\star}\end{array}$ & 2 & AS & & $\begin{array}{l}\text { Mangala giri } \\
\text { and Razvi }{ }^{29}\end{array}$ & 20 & $\mathrm{U}(\mathrm{L})^{*}$ & 2 & AS & & $\begin{array}{c}\text { Mangalag } \\
\text { iri and } \\
\text { Razvi }^{29}\end{array}$ \\
\hline
\end{tabular}




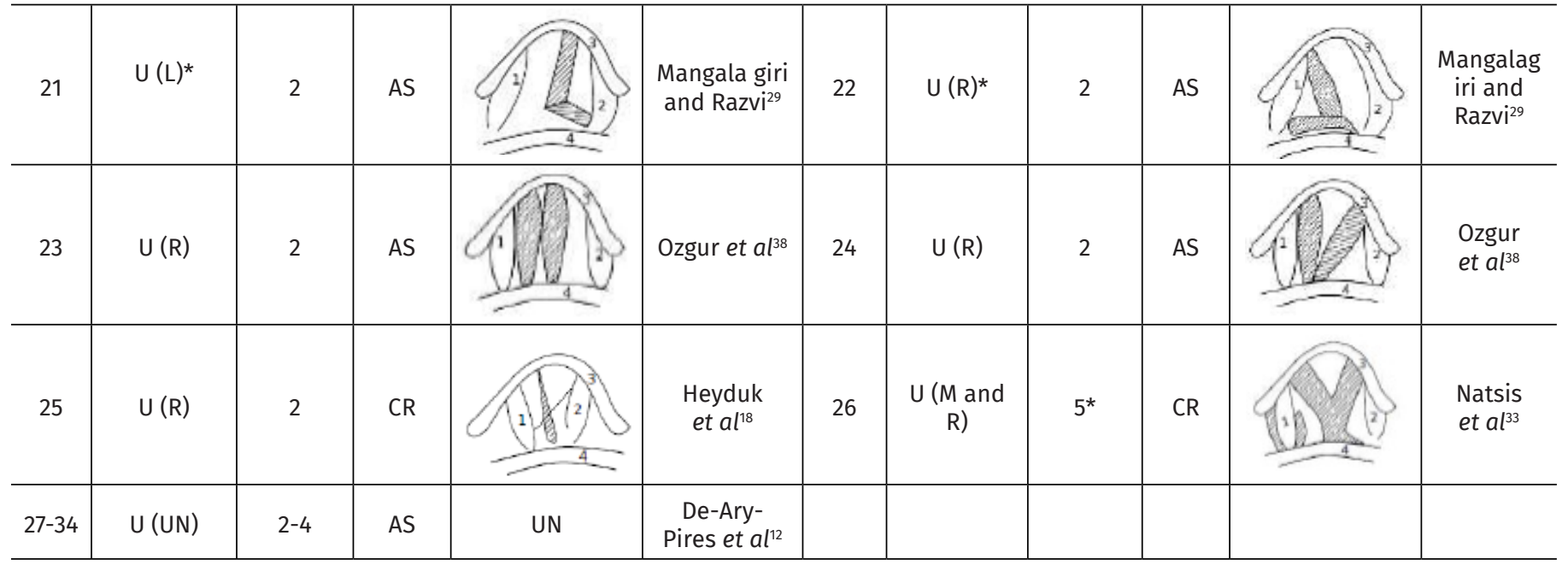

Bilateral symmetric variation

\begin{tabular}{|c|c|c|c|c|c|c|c|c|c|c|c|}
\hline $\begin{array}{c}\text { Case } \\
\mathbf{N} \\
\end{array}$ & $\begin{array}{c}\text { Side and } \\
\text { symmetry }\end{array}$ & $\begin{array}{c}\text { Atypical } \\
\text { bellies }\end{array}$ & Study & Morphology & Reference & $\begin{array}{c}\text { Case } \\
\mathbf{N}\end{array}$ & $\begin{array}{c}\text { Side and } \\
\text { symmetry }\end{array}$ & $\begin{array}{c}\text { Atypical } \\
\text { bellies }\end{array}$ & Study & Morphology & Reference \\
\hline 35 & BS & 2 & CR & & Norton 35 & 36 & BS & 2 & CR & & $\begin{array}{l}\text { Holibkov } \\
\text { á and } \\
\text { Machálek }^{19}\end{array}$ \\
\hline 37 & BS & 1 & AS & & $\begin{array}{l}\text { Sargon } \\
\text { et al }{ }^{45}\end{array}$ & 38 & BS & 2 & CR & & $\begin{array}{l}\text { Uzun } \\
\text { et } a l^{56}\end{array}$ \\
\hline 38 & BS & 2 & CR & & $\begin{array}{l}\text { Yüksel and } \\
\text { Yüksel }{ }^{59}\end{array}$ & 40 & BS & $4^{*}$ & CR & & $\begin{array}{l}\text { Aktekin } \\
\text { et } a l^{2}\end{array}$ \\
\hline 41 & BS & 2 & AS & & $\begin{array}{l}\text { Sakamot o } \\
\text { and Akita } 43\end{array}$ & 42 & BS & 6 & AS & & $\begin{array}{c}\text { Sakamoto } \\
\text { and } \\
\text { Akita }^{43}\end{array}$ \\
\hline 43 & BS & 2 & AS & & $\begin{array}{l}\text { Sakamot o } \\
\text { and Akita }\end{array}$ & 44 & BS & 2 & CR & & $\begin{array}{l}\text { Reyes } \\
\text { et } a l^{42}\end{array}$ \\
\hline 45 & BS & 2 & AS & & $\begin{array}{l}\text { Liquidat o } \\
\text { et } a l^{26}\end{array}$ & 46 & BS & 2 & CR & & $\begin{array}{l}\text { Bakirci } \\
\text { et } a l^{6}\end{array}$ \\
\hline 47 & BS & 2 & AS & & Ozgur et $a l^{37}$ & 48 & BS & 4 & AS & & $\begin{array}{l}\text { Ozgur } \\
\text { et } a l^{37}\end{array}$ \\
\hline 49 & $\mathrm{BS}^{*}$ & 2 & AS & & $\begin{array}{l}\text { Mangala giri } \\
\text { and Razvii }\end{array}$ & 50 & BS & 2 & CR & & $\begin{array}{l}\text { Singh } \\
\text { et } a l^{49}\end{array}$ \\
\hline 51 & BS & 2 & CR & & $\begin{array}{c}\text { Mascaro } \\
\text { et } a l^{30}\end{array}$ & 52 & BS & 2 & CR & & $\begin{array}{l}\text { Thakur } \\
\text { et } a l^{53}\end{array}$ \\
\hline 53 & BS & 2 & CR & & Rani et $a l^{41}$ & 54 & BS & 2 & CR & & $\begin{array}{l}\text { Buffoli } \\
\text { et } a l^{9}\end{array}$ \\
\hline
\end{tabular}






Bilateral asymmetric variation

\begin{tabular}{|c|c|c|c|c|c|c|c|c|c|c|c|}
\hline $\begin{array}{c}\text { Case } \\
\mathbf{N}\end{array}$ & $\begin{array}{l}\text { Side and } \\
\text { symmetry }\end{array}$ & $\begin{array}{c}\text { Atypical } \\
\text { bellies }\end{array}$ & Study & Morphology & Reference & $\begin{array}{c}\text { Case } \\
\mathbf{N}\end{array}$ & $\begin{array}{l}\text { Side and } \\
\text { symmetry }\end{array}$ & $\begin{array}{c}\text { Atypical } \\
\text { bellies }\end{array}$ & Study & Morphology & Reference \\
\hline 58 & BA & 4 & CR & & Michna ${ }^{31}$ & 59 & BA & $\begin{array}{c}3 \\
\text { (fibrous } \\
\text { band) }\end{array}$ & CR & & $\begin{array}{c}\text { Sarikçioğl } \\
\text { u et } a l^{46}\end{array}$ \\
\hline 60 & BA & $4^{*}$ & CR & & $\begin{array}{c}\text { Holibko vá } \\
\text { and Machále } \\
\text { k }^{19}\end{array}$ & 61 & BA & 4 & AS & & $\begin{array}{l}\text { Sargon } \\
\text { et al }{ }^{45}\end{array}$ \\
\hline 62 & BA & 4 & AS & & $\begin{array}{l}\text { Sargon } \\
\text { et } a l^{45}\end{array}$ & 62 & BA & $\begin{array}{c}1 \\
\text { acce } \\
\text { sory } 2 \\
\text { (atrophy } \\
\text { of the } \\
\text { ABDM) }\end{array}$ & AS & & $\begin{array}{l}\text { Sargon } \\
\text { et al }{ }^{45}\end{array}$ \\
\hline 64 & BA & 2 & AS & & $\begin{array}{l}\text { Sargon } \\
\text { et } a l^{45}\end{array}$ & 65 & BA & 2 & CR & & $\begin{array}{l}\text { Peker } \\
\text { et } \mathrm{al}^{39}\end{array}$ \\
\hline 66 & BA & 7 & CR & & $\begin{array}{l}\text { Fujimur a } \\
\text { et } a l^{13}\end{array}$ & 67 & BA & 2 & AS & & $\begin{array}{l}\text { Sakamoto } \\
\text { and Akita } \\
{ }_{43}\end{array}$ \\
\hline 68 & BA & 3 & CR & & $\begin{array}{l}\text { Turan- } \\
\text { Ozdemir } \\
\text { et al }{ }^{55}\end{array}$ & 69 & BA & 2 & CR & & $\begin{array}{l}\text { Loukas } \\
\text { et } a l^{27}\end{array}$ \\
\hline 70 & BA & 2 & AS & & $\begin{array}{l}\text { Liquidat o } \\
\text { et } a l^{26}\end{array}$ & 71 & BA & 4 & AS & & $\begin{array}{l}\text { Ozgur } \\
\text { et } a l^{3}\end{array}$ \\
\hline 72 & BA & 5 & AS & & $\begin{array}{l}\text { Ozgur } \\
\text { et } a l^{37}\end{array}$ & 73 & BA & 5 & AS & & $\begin{array}{l}\text { Ozgur } \\
\text { et } a l^{37}\end{array}$ \\
\hline 74 & BA & 4 & AS & & $\begin{array}{l}\text { Ozgur } \\
\text { et } a l^{37}\end{array}$ & 75 & BA & 1 & CR & & $\begin{array}{l}\text { Sevinç } \\
\text { et } a l^{47}\end{array}$ \\
\hline 76 & $\mathrm{BA}^{*}$ & 4 & AS & & $\begin{array}{l}\text { Mangala giri } \\
\text { and Razvi }{ }^{29}\end{array}$ & 77 & BA & 4 & CR & & $\begin{array}{c}\text { Yamazaki } \\
\text { et al }{ }^{58}\end{array}$ \\
\hline 78 & BA & 3 & CR & & Kyung et al23 & 79 & BA & $3^{*}$ & CR & & $\begin{array}{l}\text { Zdilla } \\
\text { et } a l^{60}\end{array}$ \\
\hline 80 & BA & 3 & CR & & Raju et al ${ }^{40}$ & 81 & BA & 2 & CR & & $\begin{array}{l}\text { Bang } \\
\text { et al }\end{array}$ \\
\hline
\end{tabular}




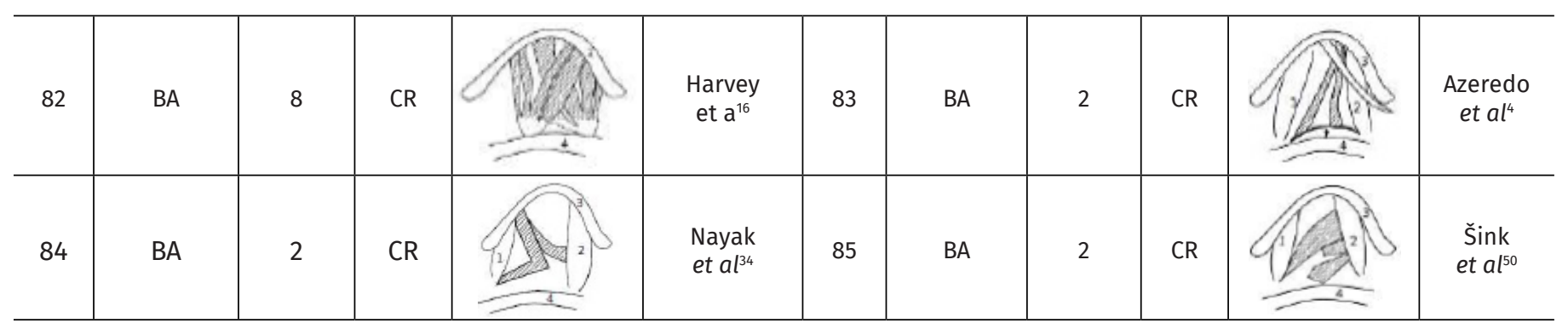

Agenesis, Atrophies and Unknown morphology

\begin{tabular}{|c|c|c|c|c|c|c|c|c|c|c|c|}
\hline $\begin{array}{c}\text { Case } \\
\mathbf{N}\end{array}$ & $\begin{array}{c}\text { Side and } \\
\text { symmetry }\end{array}$ & $\begin{array}{c}\text { Atypical } \\
\text { bellies }\end{array}$ & Study & Morphology & Reference & $\begin{array}{c}\text { Case } \\
\mathbf{N}\end{array}$ & $\begin{array}{c}\text { Side and } \\
\text { symmetry }\end{array}$ & $\begin{array}{c}\text { Atypical } \\
\text { bellies }\end{array}$ & Study & Morphology & Reference \\
\hline 86 & $\mathrm{U}(\mathrm{L})$ & $\begin{array}{c}1 \text { (atrophy } \\
\text { of the left } \\
\text { ABDM) }\end{array}$ & AS & & $\begin{array}{l}\text { Larsson and } \\
\text { Lufkin }^{24}\end{array}$ & $87-96$ & B (UN) & $1-4$ & AS & UN & $\begin{array}{l}\text { De-Ary- } \\
\text { Pires } \\
\text { et } a l^{12}\end{array}$ \\
\hline $\begin{array}{l}97- \\
109\end{array}$ & NC & $1-4$ & AS & UN & Ozgur et $a l^{37}$ & 110 & BS & $\begin{array}{c}2 \\
\text { (atrophy } \\
\text { and } \\
\text { off- site } \\
\text { of the } \\
\text { ABDM) } \\
\end{array}$ & AS & U & \\
\hline 111 & $\mathrm{U}(\mathrm{L})$ & $\begin{array}{c}1 \\
\text { (atrophy } \\
\text { of the left } \\
\text { ABDM) }\end{array}$ & CR & & $\begin{array}{c}\text { Ochoa - } \\
\text { Escuder o } \\
\text { and Juliano }\end{array}$ & 112 & U (R) & $\begin{array}{c}1 \\
\text { (atrophy } \\
\text { of the } \\
\text { left } \\
\text { ABDM) }\end{array}$ & CS & NC & $\begin{array}{l}\text { Gibson } \\
\text { et } a^{115}\end{array}$ \\
\hline 113 & $\mathrm{U}(\mathrm{L})$ & $\begin{array}{c}1 \\
\text { (atrophy } \\
\text { of the left } \\
\text { ABDM) }\end{array}$ & CS & NC & $\begin{array}{l}\text { Gibson } \\
\text { et } a l^{15}\end{array}$ & 114 & $\mathrm{U}(\mathrm{L})$ & $\begin{array}{c}1 \\
\text { (atrophy } \\
\text { of the } \\
\text { left } \\
\text { ABDM) }\end{array}$ & & NC & $\begin{array}{l}\text { Gibson } \\
\text { et } a l^{5}\end{array}$ \\
\hline
\end{tabular}

BS: bilateral symmetric; BA: bilateral asymmetric; MS: median symmetric; U: Unilateral; AS: anatomical study; CR: case report; CS: clinical study; NC: not clear; UN: unknown; C: crossover; L: left; M: median; R: right; *: number of atypical bellies and or symmetry according to our interpretation.

We would like to emphasise here that our diagrams do not necessarily represent the author's view but our interpretation of the reports.

The frequency of the anatomical variations of the digastric muscle reported in the literature is variable (2.7 to $69.6 \%) .{ }^{15,27,3}$ Considering that this is a common and highly variable anomaly, authors have proposed different ways to classify the variations of the digastric muscle in groups ${ }^{8,10,12}$ or individually e.g. m. Mentohyoid, m. Interdigastricusor the "arrowhead" type, recently proposed by Zdilla and colleagues. ${ }^{18}$

Yamada $^{8}$ classified the accessory belly of the ABDM,based on its origin and insertion as: atavistic; origin; insertion; mixed; complex and defect types. Using Yamada's classification for digastric muscle variations, Fujimura and colleagues ${ }^{17}$ suggest that authors should also consider the area of insertion of the variation.

On the other hand, De-Ary-Pires and colleagues10 classified variations of digastric muscle into 10 different patterns (A-J), a result of the combinations of position and number of accessory anterior and posterior belly as well as the morphology of intermediate tendon. The absent digastric bellies were classified as type $\mathrm{K}$ or $\mathrm{L}$, and in these cases, De-Ary-Pires and colleagues10 suggest that the muscle should be defined as monogastric muscle.

Depending on the trajectory of the muscle fibres,
Ozgur and colleagues, ${ }^{15}$ classified abnormal fibres according to transposition of the median line. In the crossover type, the fibres cross the midline and on the digastric fossa type, they do not cross the midline.

In the development of this study, a database with the reported cases of anomalous belly of the ABDM was compiled. From a total of 114 cases, 62 were bilateral and 39 unilateral anomalies and 13 unknown data. Several authors s, $29,30,22,25$ reportthis variation as usually unilateral, while Liquidato et al. ${ }^{13}$ and Mangalagiri and Razvi $^{14}$ consider an equal presence of either unilateral or bilateral accessory belly. Our database revealedmore bilateral (62\%) variation of the accessory belly ABDM.

The biomechanical importance on the floor of the oral cavity and temporomandibular joint, makes the asymmetric variation on the ABDM clinically important.${ }^{31}$ From the 52 registered cases, 24 showed a symmetric pattern while 28 were asymmetric. Several authors, such as, ${ }^{32,13,14,33}$ also mention the symmetrical variations in ABDM which are uncommon in adults and extremely rare in human foetuses. ${ }^{34}$

From 39 reports of unilateral variation, 14 cases of variant belly was found on the right side, 10 on the left side and 7 located in the middle or crossing sides. There were 8 cases without side informationof 
unilateral variation. The variation presented in this report is unilateral, located mainly on the right side showing acrossover pattern. Similar cases have already been described in the literature. ${ }^{28,13,14,27,36}$

The comparative and evolutionary morphological aspects of the digastric and other supra-hyoid muscles is discussed in the anatomical treatise Quain's elements of anatomy (Bryce 1923), surprisingly almost 100 years after Zdilla et al. ${ }^{18}$ retrieved the discussion on the evolutionary and comparative aspects of the digastric and mylohyoid muscles. Theywisely suggest a new terminology "Arrowhead" for one type of anterior digastric belly variation, considering that the "arrowhead type" is analogous to mylohyoid morphology.

According to Sharpey et al., ${ }^{4}$ Standring, ${ }^{1}$ Lee and Yang $^{3}$, the mylohyoid and the anterior belly of thedigastric muscles usually exchange some fibres, also found in the present case, which can result in complete fusionbetween them forming an accessory muscle. 22,25

The rarity of the agenesis and/or atrophy of the anterior belly of the digastric muscle in a nonsyndromic populationis reported by Gibson et al. ${ }^{21}$ These authors report a $0.2 \%$, incidence while De-AryPires et al. ${ }^{10}$ reported a $1.3 \%$, incidence, and concerning the laterality, these authors picture it as an unilateral phenomenon. This was corroborated by OchoaEscudero and Juliano ${ }^{37}$ and contradicted by Kalniev et al. ${ }^{16}$ reporting a bilateral agenesis of the ABDM.
Furthermorethis variation was reported in both sexes.

Unilateral variations, such as the one described in this case, have greater clinical significance as they cause an asymmetry of the submandibular region, which may cause discrepancies in the movement of the mandible or lack of strength of the floor of the mouth. ${ }^{38,39,20,40}$ These variations are also related to dissymmetrical mandibular activity of the temporomandibular joint, headaches and chew disorders. ${ }^{31}$

It is worth pointing out that these types of variations may be confused with pathologies of the submandibular region, such as lymph node tumours, thyroglossal duct cysts or neoplasms in clinical and imaging examinations. They can also be an issue during surgical procedures in this region of the neck, given that these muscles act as reference points for some procedures. . $^{41,10,23,26,27}$

\section{Conclusions}

The digastric muscle anterior belly variation is relatively frequent, however, its presentation and number are variable and in general unique. The knowledge of these anatomical variations is crucial, since they can easily be confused with pathological conditions.

\section{Acknowledgements}

We are immensely grateful to Caio Cordeiro Mariniello for performing the artwork of the diagrams.

\section{References}

1. STANDRING S (2016) Gray's Anatomy: the anatomical basis of clinical practice. Forty-first edition. New York : Elsevier Limited.

2. MOORE KL, PERSAUD TVN, TORCHIA MG (2012) Aparelho Faríngeo, face e pescoço. Embriologia clínica. Elsevier, Rio deJaneiro. p.159-161. 3. LEE HY, YANG HJ (2016) Anterior neck muscles. In Tubbs RS, Shoja MM, Loukas M. Bergman's comprehensive encyclopedia of human anatomic variation. John Wiley \& Sons, New Jersey. p. 228.

4. SHARPEY W, THOMSON A, SCHAEFER EA, et al. (1878) Quain's Elements of anatomy, Vol I Section 03: Myology 8thed. New York. Pg 282-3.

5. TESTUT L (1884) Les Anomalies Musculaires Chez l'homme. Libraire de L'academie de Medicine, Paris.

6. BRYCE TH. (ed.) (1923) Quain's elements of anatomy. Vol. 4, Part 2: Myology 11th ed. London.

7. MACALISTER A (1866 - 1869) On Muscular Anomalies in Human Anatomy, and Their Bearing upon Homotypical Myology. Proceedings of the Royal Irish Academy (1836-1869), Vol. 10, pp. 121-164. https:// www.jstor.org/stable/20488978 (accessed: 13/12/2018 12:27 UTC).

8. YAMADA S (1935) Baobachtungenüber den Venter anterior des Musculus digastricus mandibulaebeijapanischenErwachsenen und Foeten. ActaAnat Nippon, 8: 303-47.

9. SARGON MF, CELIK HH (1994) An abnormal digastric muscle with three bellies. SurgRadiol Anat. 16:215-216.

10. DE-ARY-PIRES, ARY PIRES R, PIRES-NETO MA (2003) The human digastric muscle: Patterns and variations with clinical and surgical correlations. Ann Anat, 185: 471-479.

11. SAKAMOTO Y, AKITA K (2004) Supernumerary muscle bundles in the submental triangle: their positional relationships according to innervation. SurgRadiol Anat;26:245-53.DOI 10.1007/s00276-0040227-1.
12. OZGUR Z, GOVSA F, OZGUR T (2007) The cause of the difference in the submental region: aberrant muscle bundles of the anterior belly of the digastric muscle. J Craniofac Surg.;18:875-881.

13. LIQUIDATO BM, BARROS MD, ALVES AL, PEREIRA CSB (2007) Anatomical study of the digastric muscle: Variations in the anterior belly. Int J Morphol, 25(4): 797-800.

14. MANGALAGIRI AS and RAZVI MRA (2009) Variations in the Anterior Belly of Diagastric. Int J Health Sci (Qassim), 3:257-262.

15. OZGUR Z, GOVSA F, CELIK S, OZGUR T. (2010) An unreported anatomical finding: unusual insertions of the stylohyoid and digastric muscles. SurgRadiol Anat, 32: 513-517.

16. KALNIEV $M$, KRASTEV D, KRASTEV $N$, VIDINOV $K$, VELTCHEV L, APOSTOLOV A et al. (2013) A rare variation of the digastric muscle. Clujul Med. 86(4):327-9.

17. FUJIMURA A, ONODERA M, FENG X, OSAWA T, NARA E, NAGATO $S$ et al. (2003) Abnormal anterior belly of the digastric muscle: A proposal for the classification of abnormalities. Anat Science Inter, 78: 185-188. 18. ZDILLA MJ, MANGUS RR, SWEARINGEN JV, MILLER KD, LAMBERT HW (2018) The submental arrowhead variation of the mylohyoid and anterior belly of digastrics muscles. SurgRadiol Anat 40:1429-1436. doi.org/10.1007/s00276-018-2110-5.

19. KIM SD, LOUKAS M (2019) Anatomy and variations of digastric muscle. Anat Cell Biol 52(1):1-11. https://doi.org/10.5115/ acb.2019.52.1.1.

20. YAMAZAKI Y, SHIBATA M, USHIKI T, ISOKAWA K, SATO N (2011) Bilateral, asymmetric anomalies of the anterior bellies of digastric muscles. J Oral Sci, 53:523-527.

21. GIBSON D, DWIVEDI RC, BOWLES C, BRENNAN PA (2016) Atrophy of anterior digastric muscle detected during ultrasound of the neck - a prospective clinical study. Br J Oral Maxillofac Surg 54:331-333. 
http://dx.doi.org/10.1016/j.bjoms.2015.12.009.

22. SARGON MF, CELIK HH (1994) An abnormal digastric muscle with three bellies. SurgRadiol Anat. 16:215-216.

23. TURAN-OZDEMIR S, OYGUCU IH, KAFA IM (2004) Bilateral abnormal anterior bellies of digastric muscles. Anat Science Int, 79: 95-97

24. BONALA N, KISHAN TV, SRI PAVANI B, MURTHY PVN(2015) Accessory belly of digastric muscle presenting as a submandibular space mass. Med j Armed Forces India. 71:S506-S508. doi:10.1016/j. mjafi.2015.06.022.

25. PEKER T, TURGUT HB, ANILA (2000) Bilateral anomaly belliesof digastric muscle. SurgRadiol Anat, 22: 119-121. https://www. biodiversitylibrary.org/item/44882\#page/308/mode/1up (assessed $21 / 12 / 18$ )

26. ZDILLA MJ, SOLONINKA HJ, LAMBERT HW (2014) Unilateral duplication of the anterior digastric muscle belly: a case report with implications for surgeries of the submental region. J Surg Case Rep, 12: 1-2.

27. LARSSON SA, LUFKIN GB (1987) Anomalies of digastric muscles: CT and MR demonstration. J Comput Assist Tomogr. 11: 422-5

28. MICHNA H (1989) Anatomical anomaly of human digastrici muscle. Acta Anat 134:263-4.

29. CELIK HH, YILMAZ E, ATASEVER A, DURGUN B, TANER D (1993) Observation of anomalous triplication of unilateral anterior digastric muscle. Clin Anat.; 6: 353-5.

30. ANDREO JC, NAVARRO JAC, TOLEDO FILHO JL (1997) Anatomical study on the variations of the anterior belly of the digastric muscle. Rev ChilAnat, 15:111-114.

31. AKTEKIN M, KURTOĞLU Z, OZTÜRK AH (2003) A bilateral and symmetrical variation of the anterior belly of the digastric muscle. Acta Med Okayama. 57(4):205-7.

32. BUFFOLI B, LANCINI D, FERRARI M, BELOTTI F (2016) Symmetrical anatomical variant of the anterior belly of the digastric muscle: clinical implications. Folia Morphol 75:122-6. DOI: 10.5603/FM.a2015.0077.

33. ZIÓŁKOWSKI M, MAREK J, KŁAK A (1984) The human digastric muscle in the fetal period. Folia Morphol, 43: 243-249.

34. HEYDUK CR, ALLCOCK CE AND INGLIS S (2016) Quantification of accessory digastric bellies. Int J AnatVar (IJAV) 9:76-8. https:// www.pulsus.com/scholarly-articles/quantification-of-accessorydigastric-bellies.html.

35. OCHOA-ESCUDERO M, JULIANO AF (2016) Unilateral hypoplasia with contralateral hypertrophy of anterior belly of digastric muscle: a case report. SurgRadiol Anat. 38:973-4. DOI 10.1007/s00276-0161630-0.

36. STOCKSTILL JW, HARN SD, UNDERHILL TE (1991) Clinical implications of anomalous muscle insertion relative to jaw movement and mandibular dysfunction: the anterior belly of the digastric muscle in a cadaver. J Craniomandib Disord, 5:64-70.

37. REYES G, CONTRERAS C, RAMIREZ LM, BELLESTEROS LE (2007) The digastric muscle's anterior accessory belly: Case report. Med Oral Patol Oral Cir Bucal, 12: 341-343.

38. HARVEY JA, CALL Z, PETERSON K, WISCO J (2015) Weave pattern of accessory heads to the anterior digastric muscle. SurgRadiol Anat, 37:1001-1004.

39. UZUN A, ALUCLU A, KAVAKL A (2001) Bilateral accessory anterior bellies of the digastric muscle and review of the literature. AurisNasus Larynx, 28:181-183.

40. ACCIOLY LINS CCS, CORRÊA DIM, LIMA RS, SILVA CC, VILLAROUCO FMO, SILVA NA . (2017) Anatomical Study and Variation of the Anterior Belly of Digastric Muscle: Case Report. MOJ Anat\&Physiol 3(4): 00099. DOI: $10.15406 /$ mojap.2017.03.00099.

41. AZEREDO RA, CESCONETTO LA, TORRES LHS (2016) Bilateral variation of anterior belly of digastric muscle. J Morphol Sci. 33:215-7. http://dx.doi.org/10.4322/jms.095215.

42. BANG JH, GIL YC, YANG HJ, JIN JD, LEE JH, LEE HY (2015) Multiple Muscular Variations in the Neck, Upper Extremity, and Lower Extremity Biased toward the Left Side of a Single Cadaver. J Korean Med Sci. 2015 30(4):502-505. doi.org/10.3346/jkms.2015.30.4.502 43. BAKIRCI S, KAFA IM, UYSAL M, SENDEMIR E (2007) Anterior belly anomalies of the digastric muscle: Case report. Eur J Anat, 11 (3): 201203.

44. CELIK HH, ALDUR MM, OZDEMIR B, AKȘIT MD (2002) Abnormal digastric muscle with unilateral quadrification of the anterior belly. Clin Anat. 15:32-4. https://doi.org/10.1002/ca.1088.

45. GUELFGUAT M, NURBHAI N, SOLOUNIAS N (2001) Median accessory digastric muscle: Radiological and surgical correlation. ClinAnat 14: 42-6. doi:10.1002/1098- 2353(200101)14:1<42::AID-CA1007>3.0.CO;2-0 46. HEO YR, LEE JH, CHO HP (2018) Accessory Heads of Anterior Belly of Digastric Muscle in Korea. Keimyung Med J. 37(2):97-100. doi. org/10.0000/ kmj.2018.37.2.97.

47. HOLIBKOVÁ A, MACHÁLEK L (1999) A Report on Anomalies of Digastric Muscle. ActaUnivPalackiOlomucFac Med.142: 57-9.

48. KARUNAKARAN I, DHINGRA R, DHAR P (2013) Accessory digastric and mylohyoid muscles - a case report. Int J AnatVar (IJAV) 6: 179-181 49. KYUNG DS, LEE JH, LEE YP, KIM DK (2011) Bilateral variations of the head of the digastric muscle in Korean: a case report. Anat Cell Biol. 44(3):241-3. https://doi.org/10.5115/acb.2011.44.3.241.

50. LOUKAS M, LOUIS RG, KAPOS T, KWIATKOWSKA M (2005) A case of a bilateral accessory digastric muscle. Folia Morphol. 64(3):233-6 51. MASCARO MB, PICOLI LC, SANTOS FM, BONSI AB (2011) Anatomical variation of the anterior belly of the digastric muscle: Case report and clinical implications. J Morphol Sci. 28(1):72-75.

52. NATSIS K, PIAGKOU M, VROCHIDIS P, PAPADOPOULOU E, LAZARIDIS N (2018) Unilateral asymmetrical anterior bellies of the digastric muscle in coexistence with accessory muscle bundles in the submental triangle: A rare case report. Morphologie. Jun;102(337):8386. doi: 10.1016/j.morpho.2017.10.001.

53. NAYAK SB, RAO SS, SUDARSHAN S, PRASAD AM (2017) A morphological variant of anterior belly of digastric muscle: a cadaveric case report. Bangladesh J Med Sci 16(3) 461-3.

54. NORTON MR (1991) Bilateral accessory digastric muscles. $\mathrm{Br}$ J Oral Maxillofac Surg. 29:167-8. https://doi.org/10.1016/02664356(91)90030-9.

55. RAJU S, KANCHANA L, VENU MN, RAGHU J, SRINIVASA R (2014) A Rare Bilateral Asymmetric Variation of the Anterior Belly of Digastric Muscle. Journal of Surgical Academia 4(2):29-31

56. SARIKÇIOĞLU L, DEMIR S, OĞUZ N, SINDEL M (1998) An anomalous digastric muscle with three accessory bellies and one fibrous band. SurgRadiol Anat20:453- 4.

57. SEVINÇ Ö, ÇETIN Z, BARUT Ç, BÜKEN B, ARIFOĞLU Y (2009) A complex variation of the digastric muscle: a case report. Anatomy, 3 (1). DOI: 10.2399/ana.08.025.

58. SINGH Z, KAUR G, KAUR A (2011) A variant digastric muscle. IJAV 4:120-122. https://www.pulsus.com/scholarly-articles/a-variantdigastric-muscle.html.

59. ŠINK Ž, UMEK N, CVETK.O E (2018) Cross-over type of supernumerary digastric muscle: a case report. Folia Morphol (Warsz). Dec 11. doi: 10.5603/FM.a2018.0112.

60. THAKUR A, BERTHA A AND PARMAR SK (2011). Multiple variations in neck musculature and their surgical implications. Int J AnatVar (IJAV) 4: 171-173.

61. YÜKSEL M AND YÜKSEL E A (2001) Case With Accessory Digastric Muscles and Its Clinical Importance. Ann Plast Surg 46(3):351-352.
Received: January 30, 2020

Accepted: January 5, 2021
Corresponding author

Patricia Shirley de Almeida Prado

almeidaprado.morf@gmail.com 